\title{
TWENTY YEARS OF THE COMPOSER SPEAKS SECTION IN THE NEW SOUND MAGAZINE (INTERVIEW AS A METHOD OF MUSICOLOGICAL RESEARCH)
}

\author{
Sonja Marinković* \\ University of Arts in Belgrade \\ Faculty of Music \\ Department of Musicology
}

\begin{abstract}
This paper presents analyses of the texts published in the Composer Speaks section in the New Sound magazine, on the occasion of the twentieth anniversary of its continual publishing. It sums up the achieved results, and classifies the collected materials, with special emphasis on methodology issues concerning the status of the interview as a scientific method, indicating its importance in musicological research. The most significant results are viewed from this perspective, drawing attention to the value of the contributions achieved in the research of Serbian music and the development of Serbian musicology.
\end{abstract}

Key words: Novi Zvuk, New Sound, Serbian music, musicology, methodology, interview

\begin{abstract}
Апстракт: У раду се анализирају текстови објављивани у рубрици Реч композитора у часопису Нови Звук, а поводом двадесете годишњице његовог континуираног излажења. Сумирају се постигнути резултати, класификује прикупљени материјал, а посебна пажња посвећује се методолошким питањима у вези са статусом интервјуа као научног метода, те његовог значаја за музиколошка истраживања. Из тог угла сагледавају се најзначајнији резултати и указује се на вредност оствареног доприноса истраживањима српске музике и развоју српске музикологије.
\end{abstract}

Кључне речи: Нови Звук, српска музика, музикологија, методологија, интервју

\footnotetext{
* Author contact information: marinkovica@ikomline.net

The paper was written within the project Identiteti srpske muzike u svetskom kulturnom kontekstu [Identities of Serbian Music in the World Cultural Context] by the Department of Musicology of the Faculty of Music in Belgrade, supported by the Ministry of Education, Science and Technological Development of the Republic of Serbia, under Reg, No. 177019
} 
In the New Sound magazine, the Composer Speaks section ${ }^{1}$ was conceived as one of the regular sections, published in almost every issue of the review, ${ }^{2}$ and the number of contributions published in the 38 issues of the magazine is impressive - fifty three. The concept of the section was not rigid and various texts were included. Most of them are interviews with the authors, most often the musicologist interviewing the composer, but the dynamics of this section are also enriched by various exceptions to this rule. Thus, in Issue No. 7, the authorial contribution by Ana Kotevska was published in the form of an imaginary interview with Miloje Milojević (1885-1946): an article which simulates the form of the interview, but actually uses Milojević's texts published on various occasions in the contemporary press or in personal correspondence, in order to present, in an original way, both the biographical elements and the author's opinion on numerous topical issues, among which the most prominent are his relation towards his predecessors, as well as towards tradition, contemporaries, and modernism. ${ }^{3}$ Several dialogues with original concepts were also published. In Issue No. 9, 'Interview in a Mirror' by Vladan Radovanović represents an excellent illustration of the author's avant-garde position. ${ }^{4}$ In Issue No. 13, the mutual interviews of Zoran Erić and Miloš Petrović were published, in which the authors exchanged the roles of the interviewer and the interviewee, in dealing

\footnotetext{
1 The title of the section has been generally constant - Composer Speaks - but it varied four times: once as The Ethnomusicologist Speaks (Issue No. 6, interview with Dragoslav Dević), and three times as The Musicologist Speaks (Issues Nos. 29, 33 and 35, interviews with David Fallows, Ana Kotevska and Marija Bergamo respectively), while in No. 31 it had a subtitle which specifies the nature of the published text: 'The Composer and his Performer' - an interview with Katarina Miljković and Nada Kolundžija. In Issue No. 26, in which four texts were published, including the interview with the Byzantologist Miloš Velimirović, this article was not singled out separately, but the whole section was titled The Composer Speaks. The fields of theory and pedagogy were also covered, but they were presented as intertwined with composing, which was particularly obvious in the interviews with Vlastimir Peričić, Dejan Despić and Mirjana Živković, but also with Stanojlo Rajičić and Srđan Hofman, while the creative personality of Dimitrije Golemović integrates the ethnomusicologist and the composer.

2 Issues Nos. 16 and 32 did not include this section, since they were conceived as thematic and had a number of contributions whose volume significantly exceeded the usual standard of the review (No. 16, dedicated to the $2000^{\text {th }}$ anniversary of Christianity, in one volume comprised the Serbian and the English version of the review - 302 pages in total; No. 32, dedicated to the ballad, 300 pages).

3 Ana Kotevska, 'Miris moderne slobode, Imaginarni razgovor sa Milojem Milojevićem' ['The Smell of Modern Freedom, an Imaginary Interview with Miloje Milojević'], 7, 1996, $5-14$.

4 Vladan Radovanović, 'Intervju u ogledalu' ['Interview in a Mirror'], 9, 1997, 5-12.
} 
with the thematic issue, dedicated to jazz and popular music. ${ }^{5}$ Issue No. 31 published the specific diary entries by the composer and the performer - Katarina Miljković and Nada Kolundžija - conceived as the answers to the 'theme of the day' (given in the subtitle: 'Šta nas čini nervoznim' ['What Makes us Nervous'], 'Zašto se bavimo muzikom' ['Why We Are in Music'], 'Komunikacija' ['Communication'], and so on). The text partly shows the elements of the dialogue, and partly resembles a double monologue: it presents the auto-poetic comments or the thoughts on key topics about the relationship of the performer and the author. ${ }^{6}$ Issue No. 34, which was dedicated to the $100^{\text {th }}$ anniversary of the Futurist Manifesto, published a reprint of the text from Zenit (37, November-December 1925): a note on the conversation of one of the founders of Zenitism, Branko Ve Poljanski (who is also the author of the text) with Marinetti, Depero, Prampolini and the two ladies (the last three were 'included' in the conversation only through the description of the dialogue and the attention of listeners!), which took place in Paris, on the occasion of Marinetti's discourse on the proximity of futurism and fascism. ${ }^{7}$

On two occasions, more comprehensive authorial texts were published in the Composer Speaks section. Issue No. 23, after a short introductory item by musicologist Zorica Makević, a certain In memoriam text dedicated to Ljubica Marić, presents the reprint of Marić's discourse when being inducted into the Serbian Academy of Sciences and Arts, (titled 'Monotematičnost i monolitnost oblika fuge' ['Monothematism and the Monolithism of the Fugue Form']), as well as the excerpts from the author's 'Tablice' ['Tablets'], the composer's autopoetic and poetic writings. In Issue No. 26, the interview which Svetlana Savić conducted with Dieter Kaufmann ${ }^{8}$ is followed by his comprehensive theoretical work Whom the Tenth Muse kisses, or the Birth of Acousmatic Art out of the Spirit of Music, as his theoretical contribution to the theme of the issue - acousmatics. ${ }^{9}$

5 Miloš Petrović, 'Ovo nije igra u kojoj se može dobiti ili izgubiti. Intervju sa Zoranom Erićem' ['This is not a game in which one can win or lose. An Interview with Zoran Erić'], 13, 1999, 9-13; Zoran Erić, 'Onome ko leti ne trebaju krila. Intervju sa Milošem Petrovićem' ['He who flies does not need wings. An Interview with Miloš Petrović'], 13, 1999, 15-21.

6 Kompozitor i njegov izvođač: Katarina Miljković i Nada Kolundžija, 12 dana [The Composer and His Performer: Katarina Miljković i Nada Kolundžija, 12 days], 31, 2008, 5-17.

7 REČ O FUTURIZMU: Povodom stote godišnjice Manifesta futurizma, Dijalog Marineti - Poljanski, [A WORD ON FUTURISM: On the Occasion of the $100^{\text {th }}$ anniversary of the Futurism Manifest, a dialogue Marinetti - Poljanski], 34, 2009, 1-6.

8 Svetlana Savić, 'Novi zvučni recepti Ditera Kaufmana. Razgovor sa kompozitorom' ['New Sound Recipes by Dieter Kaufmann. Interview with the Composer'], 26, 2005, $27-32$.

9 Diter Kaufman, 'Koga ljubi deseta muza ili rođenje akuzmatične umetnosti iz duha muz- 
Still, most texts were published in the form of an interview, and that is the reason why the results should be viewed in the context of a broader methodological discourse on the role, technique, characteristics, and importance of the interview and questionnaire in musicological research.

\section{The interview as a method of scientific/musicological research}

We can accept the definition that 'razgovor i upitnik spadaju u grupu postupaka pomoću kojih se prikupljaju iskustvena izvorna obaveštenja koja se stvaraju radi specifičnih potreba i ciljeva naučnog istraživanja' ['the interview and the questionnaire belong to the group of procedures of gathering the original empirical information made for the purpose of the specific needs and aims of scientific research' $]^{10}$. Thus, in the methodology of sociology, Vojin Milić quotes them as the most important research methods, much more flexible than observation, since the use of the scientific interview and questionnaire actively creates original scientific information about man and society. He observes that, without them, most of the information would never have come into being, or at least would not have been expressed in a constant and systematic form. From this perspective, the interviews published in New Sound can be considered as valuable material for the history of Serbian music. ${ }^{11}$ Therefore, it is important to analyze the key methodological issues concerning the conception of the interview.

The interview reveals past experiences and the view into the future, as well as the internal world of the subject, which cannot be achieved by scientific observation. It discerns the value system (of the subject of the interview, some group or organization), describes the beliefs, emotions, behaviour, formal and informal roles of individuals, places and sites of certain events, meetings and conflicts, as well as stories. ${ }^{12}$

The interview as a technique is also used in quantitative and qualitative research, and, besides the humanities in which it is most often used, it is also applied in clinical, psychiatric and psychological research. There is, however,

ike' ['Dieter Kaufmann: Whom the Tenth Muse Kisses or the Birth of Acousmatic Art out of the Spirit of Music'], 26, 2005, 33-39.

10 Vojin Milić, Sociološki metod (treće izdanje) [Sociological Method (third edition)], Belgrade, Zavod za udžbenike, 1996, 479.

11 Individual interviews could certainly not be qualified as 'constant and systematic activities', but, when the interviews are conceived as a permanent concept of editorial policy, they acquire a new significance. The contribution of the Composer Speaks section is considered exactly from this aspect.

12 Cf. Vojin Milić, op. cit. 
a fundamental difference between the interview in quantitative and qualitative research. The former typically reveals the facts concerning the interests of the interviewer, and the latter reveals the position of the subject of the interview pointing out what is relevant and important to him - while quantitative research primarily investigates the negative. Qualitative research necessitates comprehensive and diverse answers, while quantitative prefers short and concise replies. The interviews in qualitative research can be conducted during several meetings, while in quantitative research, with the exception of longitudinal research, interviews are, as a rule, conducted only once. ${ }^{13}$

Methodologically, in conceiving interviews, one should aspire to achieve the meaningful completeness of the information as well as the standardization of the process of collecting it, in order to provide relatively uniform and mutually comparable data. ${ }^{14}$ It is also necessary that the sample should be methodically chosen. It is in these segments that the role of the editorship is particularly stressed, in the choice of the subject and the interviewer, and the aspiration towards the standardization of the interview form, together with the particular importance of the decision by the Editorial Board of New Sound that the interview should be preceded by short, encyclopaedic, bio-bibliographical information about the author, which should give very complete and precise data about his work and creation. This was not the standard from the beginning. Of the three interviews published in the first issue, only the interview of Katarina Tomašević with Stanojlo Rajičić had an introductory note. ${ }^{15}$ In Issue No. 6, in which the interview by Ivana Vuksanović with Rajko Maksimović ${ }^{16}$ was published, for the first time, a more complex musicological text was written as an introduction to the interview, ${ }^{17}$ thus founding a specific genre of a bio-bibliographical note about the composer in New Sound, which has something of a character of an

\footnotetext{
13 Alan Bryman, Interviewing in qualitative research, in: Social Research Methods, New York, Oxford University Press, 2001, 313, from http://peoplelearn.homestead.com/MEdHOME/QUALITATIVE/Chap15.Interview.pdf, acc. $9^{\text {th }}$ March 2012.

14 In this respect, the activity of the Editorial Board is important, but the positive tradition already realized in the published contribution also influences the processes of standardization of the approach to the interview and the concept of the published text, which will be discussed later.

15 Katarina Tomašević, Razgovor sa Stanojlom Rajičićem [An Interview with Stanojlo Rajičić], 1, 1993, 17-28.

16 Ivana Vuksanović, Komunikacija kao imperativ stvaranja. Razgovor sa Rajkom Maksimovićem [Communication as the Imperative of Creation. An Interview with Rajko Maksimović], 6, 1995, 5-15.

17 Afterwards this form of text was also given at the end of the interview, as a certain explanation of what was said.
} 
encyclopaedic entry, although without its exact and rigid form, thus making it possible for the introductory comment to be suited to the subject. From Issue No. 6 onward, with the above mentioned exceptions, this practice became established.

Other means of gathering information were also used in the preparation for the interview, so that the authorial text of the interview was the result of a complex research procedure, and not the mere recording/publishing of somebody's uttered/written words.

The methodological literature dealing with the interview mentions a number of criteria of a successful interview:

- comprehensibility ${ }^{18}$

- order, with the clearly defined purpose of the interview

- clarity, which is achieved by asking simple, easy, short questions, without the use of slang words

- politeness: the subject should be allowed to finish the story, given time to think, pauses should be tolerated

- active role of the interviewer: the person should listen carefully to what is said and how it is said

- openness: reacting to what is important to the subject of the interview

- flexibility

- ability to manage the course of the conversation, which shows an understanding of what somebody wants to say

- criticism, in the sense of a readiness to confront inconsistent answers

- good memory concerning what was said before

- interpretation skill which helps to clarify and develop the potential meanings of the subject's attitudes, without imposing the interviewer's opinion

- balance: one should neither talk too much, since this makes the subject

18 In published interviews, there is occasionally a certain tension between the interviewer and the subject, because the suggested classifications, stylistic and generic specifications of some parts of the opus, the attitudes and the value judgements expressed in the interviewer's question, are considered inadequate or irrelevant by the subject. In this respect we can even observe occasional misunderstandings between the participants. Even the interview of Danijela Kulezić with Mihovil Logar, published in the first issue of the review, shows this typical 'resistance' by the subject. In spite of the efforts of the interviewer to turn the conversation towards the systematization, qualification, stylistic specification, the interview above all expresses the mood of the ninety-year old man which hovers between an eternal brightness and liveliness of spirit, and the soft melancholy of old age. On the other hand, it is amusing how the 'tension' between two characters was built by Vladan Radovanović in his 'Intervju u ogledalu' ['Interview in a Mirror'] (no. 9). 
passive, nor too little, because this makes them feel as if there were no interest in listening to their words

- constraint

- spontaneity

- ethical correctness. ${ }^{19}$

The basic planning of the interview is considered the most complex task in performing poll research. Usually there are several preparatory phases: establishing the main aims of the poll; the theoretical and operational development of the aims; adapting the operational plan for gathering information to the life experience of the subject and the decision on the form of the interview and the final structure of its basis.

The hypothetical outline must be based on theory. If the interview consists of loosely connected, theoretically undeveloped and inadequately conceived premises, the systematization of the data will not have a focal point, and will remain at the level of superficial description. The fundamental theoretical elaboration of the projected aims of the poll considers its basic substantial tasks. There are also important decisions about the language of the poll, the number and the type of the questions, as well as their order.

In gathering autobiographical data ${ }^{20}$ the so-called soft interview is recommended, or, as it is more often called today, the research interview. If a qualified worker or an expert is being interviewed about their work or professional experience, it is neither necessary nor useful to frame the interview rigidly according to a previously established detailed plan. The interview deals with experiences which are permanently incorporated in the subject's personality, and the general incentive is sufficient to induce them to express their attitude and give lots of specific information. ${ }^{21}$ In such interviews the mutual relationship between

\footnotetext{
19 Alan Bryman, op. cit., 318; Steinar Kvale, Interviews: An introduction to qualitative research interviewing, Newbury Park, CA: Sage, 1996, from http://www.inside-installations. org/OCMT/mydocs/Microsoft $\% 20$ Word\%20-\%20Booksummary_Interviews_SMAK_2.pdf 20 The standards of the autobiographical interview were established in the Paris Review, published since 1953, thanks to the editors George Plimpton and Peter Matthiessen. In musicology, the unavoidable examples are the famous Craft's interviews with Stravinsky (it is no coincidence that they were mentioned several times in the published interviews). In our country, Miloš Jeftić and Dragoslav Adamović, with their numerous interviews, made an important contribution to historiography. Recently, the methodological contributions to the analyses of these topics were made by: Sarah Anne Johnson, The Art of the Author Interview and Interviewing Creative People, Lebanon, University Press of New England, 2005; Kathryn Roulstone, Reflective Interviewing: A guide to Theory and Practice, London, SAGE Publication, 2010.

21 Cf. Vojin Milić, op. cit., 512.
} 
the interviewer and the subject is very important, as well as the motivation for taking part in the poll. ${ }^{22}$ The important prerequisites for achieving the purpose are a sound theoretical understanding of the researched problem and sufficient experience in conducting interviews. Problems may arise, above all, concerning psychology: the relationship between remembering and forgetting, general personality structure, and the importance of specific questions in the life of the individual - but they can also be epistemological (competence, a different level of information and interest, familiarity with the facts, frankness and correctness of the information acquired through self-observation) and social (the information can be public, confidential, classified and private).

Analyzing the interviews (not the other types of texts published in the Composer Speaks section) in New Sound, from this methodological perspective, leads us to several important conclusions.

1. Although the generic variety of the texts and the intention of the editorship to conceive the Composer Speaks section as dynamic and diversified has been already mentioned, it is easy to notice that this variety is a consequence of the careful consideration of the concept, and that the aims of the poll and the value criteria in the choice of the subjects are also very prominent. Thus, of some fifty contributions, only thirteen ${ }^{23}$ deal with authors who are not immediately connected with Serbian music, which confirms the primary intention of gathering the information relevant for the national historiography. Also, considering that New Sound was, from the beginning, published bilingually, this section provides foreign readers with information about the key creative figures in Serbian music. Among the 'foreign' contributions, there are five written by Jelena Novak: interviews with Philip Glass, ${ }^{24}$ Louis Andrissen, ${ }^{25}$ Steve Reich, ${ }^{26}$

22 The best example of this might be the interview which Branka Radović conducted with Nikola Hercigonja, published in Issue No. 3. The sum of answers to the first five questions consists of six sentences, one of which consisted of only one word. The answer to the sixth question in the interview, asked ten years before those five, and added to this 'attempt' at an interview, filled up four pages of text: it was multi-layered, analytical, engaged, meaningful (concerning the questions which were not asked, but which the author considers important), and completely different compared with the resignation and disinterestedness expressed in the current interview.

23 Twelve interviews, and one authorial text by Dieter Kaufmann.

24 Jelena Novak, 'Sve je dosegnuto. Razgovor sa Filipom Glasom' ['Everything Available', Conversation with Philip Glass], 14, 15-21.

25 Jelena Novak, 'Muzika o muzici. Razgovor sa Lujem Andrisenom' ['Music about Music, Conversation with Louis Andriessen'], 18, 5-19.

26 Jelena Novak, 'Trenirane razlike. Razgovor sa Stivom Rejšom' ['Trainable Differences, Conversation with Steve Reich'], 22, 2003, 12-20. 
Ivar Frounberg, ${ }^{27}$ and Miguel Azguime, ${ }^{28}$ which are characterized by exclusivity, meticulous preparation and a high level of informativeness, as well as the conversations of Tatjana Petrović with Rodion Shchedrin, ${ }^{29}$ and Igor Radeta with Krzysztof Penderecki. ${ }^{30}$ Two meaningful, comprehensive contributions by Vojislav Pantić, interviews with jazz musicians, ${ }^{31}$ Maria Schneider ${ }^{32}$ and Brad Mehldau, ${ }^{33}$ confirm that the review was open to contributions from the other musical practices of its time, and not only to the academic classical tradition. The interviews conducted by Mirjana Veselinović Hofman with the composer Eduardo Miranda ${ }^{34}$ and musicologist David Fallows, ${ }^{35}$ as well as the interview by Svetlana Savić with Dieter Kaufmann ${ }^{36}$, corresponded with the themes of the issues and have primarily theoretical, general significance, as a form of current expert discussion about key professional issues.

2. The point of the section was, therefore, the contribution to the national historiography, and it was undoubtedly oriented primarily towards composing. ${ }^{37}$

27 Jelena Novak, 'Muzika o nestajanju vremena. Razgovor sa danskim kompozitorom Ivarom Frunbergom' ['Music on Having Time to Disappear, Conversation with Danish composer Ivar Frounberg'], 26, 2005, 53-60.

28 Jelena Novak, 'Plima zvuka. Razgovor sa Migelom Azgimom' ['Sound Tide, Conversation with Miguel Azguime'], 30, 2007, 5-12.

29 Tatjana Petrović, 'Publiku volim da ščepam za grlo. Razgovor s Rodionom Ščedrinom' ['I Like to Seize the Audience by its Throat!' An Interview with Rodion Shchedrin'], 15, 2000, $28-31$.

30 Igor Radeta, Interview with Krzysztof Penderecki, 37, 2011, 5-14.

31 New Sound does not publish interviews with performers, and these two interviews do not represent an exception: the fact that the musicians are primarily presented as performers is, in essence, the result of the peculiarity of jazz music, in which the personalities of the author and the performer permeate each other.

32 Vojislav Pantić, 'Ples zvučnih skulptura. Razgovor sa Marijom Šnajder' ['The Dance of the Sound Sculptures. Interview with Maria Schneider'], 19, 16-31.

33 Vojislav Pantić, 'Žudnja u srcu stvaranja. Razgovor sa Bredom Meldouom, džez pijanistom' ['Desire in the Heart of Creativity. An Interview with Brad Mehldau, Jazz Pianist'], 21, 2003, 15-28.

34 Mirjana Veselinović Hofman, 'Odgovornost nalaženja prave ravnoteže. Razgovor sa Eduardom P. Mirandom' ['The Responsibility of Finding the Right Balance. An Interview with Eduardo P. Miranda'], 20, 15-26.

35 Mirjana Veselinović Hofman, 'Prima la musica kao muzikološki kredo. Razgovor sa Dejvidom Felouzom' ['Prima la Musica as A Musicological Credo. An Interview with David Fallows'], 29, 2007, 5-11.

36 Svetlana Savić, 'Novi zvučni recepti Ditera Kaufmana. Razgovor sa kompozitorom' ['The New Sound Cookbook by Dieter Kaufmann. An Interview with the Composer'], 26, 2005, 27-32.

37 We have already mentioned the exceptions: the interviews with the ethnomusicologists 
In spite of the obvious intention to respect the chronology, the dates of birth of the authors were not the primary criteria for the order, and it certainly does not reflect the attitude of the editorship about the subject's contribution to Serbian musical culture, but represents the result of several criteria, ${ }^{38}$ among others elements, the readiness of the author to be interviewed for the New Sound.

3. The interviews did not have a previously assigned form, and they also differ in size. The best examples of this are three very different contributions published in the first issue; the interviews with the three members of the 'Prague Group' of composers: Ljubica Marić, Mihovil Logar and Stanojlo Rajičić. The first two interviews are concise (9-12,13-16), while the third is of considerable length and very varied in content (17-28). The interview by Zorica Makević with Ljubica Marić ${ }^{39}$ was conducted solely about poetics: about role models (the composer singled out Palestrina and Bach), about the relation towards the Octoechos and folklore as inspiration, as well as about the relation with the text. Concerning facts, it does not reveal much; it is beautifully articulated, but the essence remains intangible, which could be illustrated by Marić's expression: 'Ptica kad leti ona ne zna kako. Ptica LETI...' ['When the bird flies, it does not know h o w. The bird FLIES...']. In spite of the active attitude of the musicologist and the skilfully phrased questions, the answers were 'elusive'. The similar, already mentioned 'resistance' of the subject to the musicological observations, as we have already mentioned, is also felt in the interview by Danijela Kulezić with Mihovil Logar. ${ }^{40}$ It is also interesting that Logar, like Marić, mentioned only classics as his role models - Bach, Mozart, Beethoven, Puccini, and Strauss. Newer music is practically non-existent, except when it is mentioned in a negative context. The young generation of composers is completely absent from Logar's view of music, even his most successful student, Aleksandar Obradović, with whom he remained in warm, friendly relations until his death. The interview with Stanojlo Rajičić was conducted in different circumstances: it is the result of numerous meetings Katarina Tomašević

Dragoslav Dević (No. 17) and Dimitrije Golemović (29); musicologists Miloš Velimirović (16), Nadežda Mosusova (21), Ana Kotevska (33) and Marija Bergamo (35); the authors in whose works composing and scientific work are intertwined - Vlastimir Peričić (2), Dragutin Gostuški (2), Nikola Hercigonja (3), Dejan Despić (15) and Mirjana Živković (25), while the exploration of the pedagogical aspect of the work of the interviewed subjects was also represented, according to their engagement in pedagogical work.

38 The anniversaries, correspondence with the theme of the issue, awards, prizes and so on.

39 Zorica Makević, 'Vreme koje nas nosi dalje. Razgovor sa Ljubicom Marić' ['The Time which Takes us Further. An Interview with Ljubica Marić'], 1, 1993, 9-12.

40 Danijela Kulezić, Razgovor sa Mihovilom Logarom [An Interview with Mihovil Logar], 1, 1993, 13-16. Cf. footnote No. 18. 
had with the composer, which took place during preparations for the television programme made that year. Rajičić answered twenty-three questions: meaningfully, comprehensively, and informatively. He talked about his work, his life, but also about the music life in Serbia in general, and his sharp, critical, uncompromising judgments and attitudes dominated his expression. The introductory note about the author is concise, but still informative, because it positions and evaluates the author, establishing a platform for the conversation, and also has elements of methodological determination. ${ }^{41}$ Her example was later followed by Dejan Despić in his interview with Vlastimir Peričić, and Bojana Žižić in the interview with Dragutin Gostuški.

4. The concept of meticulous methodological consideration of the content of the interview is continued by Tijana Popović Mlađenović, in her interview with Srdan Hofman. ${ }^{42}$ According to the author of the interview, the questions were asked in order to "podstakla (...) govor o nekim osobenostima autorovog kompozicionog prosedea, o posebnostima njegove poetike uopšte' ['induce (...) conversation about certain peculiarities of the author's composing procedure, about the particularities of his poetics in general'] ${ }^{43}$ But they also deal with essential problems concerning the process of composing, and the interview provides the answers which are relevant for understanding the current moment in musical creation. Reading Hofman's words today, we can regretfully observe that he was reasonably warning against possible sidetracks: 'A šta će u budućnosti biti ideje za muziku uopšte, ne trudim se da predviđam. Nadam se ipak da surogati kao pompezni "ekspresivni" akademizam i bezlični eklekticizam "sinteza" sentimentalnih stranputica muzike neće biti nametnuti kao autentične ideje o delu' ['I do not try to foresee what the ideas for music, in general, will be in the

41 The author finishes the introductory note with auto-reflection, which testifies that she also thought about the methodological aspects of the interview: 'Bez želje da se strogo pridržavamo biografskih detalja sa kojima je stručna javnost već podrobno upoznata, opredelili smo se za slobodnu formu intervjua, u kome kompozitor, govoreći o ključnim momentima svog života i rada, ležerno i spontano, ali retko kad bez kritičkog tona, otvoreno izlaže svoje mišljenje i poglede na minule i aktuelne probleme našeg muzičkog života' ['With no wish to stick rigidly to the biographical details, with which the expert world is already familiar, we have chosen the free form of the interview in which the composer, talking about the key moments of his life and work, easily and spontaneously, but seldom without a critical tone, openly expresses his opinion and attitude about the past and present problems of our music life.'] . Cf. Katarina Tomašević, Razgovor sa Stanojlom Rajičićem [An Interview with Stanojlo Rajičić], 1, 1993, 17.

42 Tijana Popović, 'Višestrukost i koherentnost. Razgovor sa Srđanom Hofmanom' ['Multiplicity and Coherence. An Interview with Srđan Hofman'], 3, 1994, 11-18.

43 Ibid, 11. 
future. I hope that surrogates, like the pompous "expressive" academism, and the bland eclecticism of the "synthesis" of the sentimental sidetracks of music, will not be imposed as authentic work ideas']. ${ }^{44}$ The other authors also showed a pronounced need to talk about what is happening HERE AND NOW, which is understandable, considering the dramatic social circumstances in which New Sound began its cultural and scientific mission. This was maybe most explicitly expressed in the words of Dragutin Gostuški ${ }^{45}$, but was also typical of the statements of Enriko Josif ${ }^{46}$ and others. They also indicate the anticipation of certain future phenomenon. Josif's words seem to herald some impending conflicts in Serbian music:

44 Ibid, 14.

45 Bojana Žižić, Razgovor sa Dr. Dragutinom Gostuškim [An Interview with Dragutin Gostuški, Ph.D.'], 2, 1993, 11-21. Gostuški concludes his interview with the following words: 'Ja sam danas, Vama, učinio vrlo ozbiljan izuzetak. Muzika je izišla iz orbite mog razmišljanja dosta davno. Jer, moje su misli uperene ka nečem drugom i obuzete onim što bi neko nazvao politikom, a što ni u kom slučaju nije politika. Ja se time ne bavim. Razlika je $\mathrm{u}$ tome što se u normalnim zemljama, onim koje nisu u ratnom niti revolucionarnom stanju, politika menja a ljudi su živi i zdravi. Kod nas je pitanje politike postalo pitanje egzistencije. Primećujemo među mojim prijateljima dve vrste individualne reakcije na to. Neki koji su daleko srećniji, i kojima zavidim, potpuno su uspeli da se izoluju od svega. Ne čitaju novine, ne gledaju TV, ne slušaju radio, čitaju svoje knjige, bave se naučnim radom i tako uspevaju da zadrže prisustvo duha. Drugi kao što sam ja, ne mogu od toga da se otrgnu, tako da je razmišljanje o muzici dosta daleko od mene. Koncerti su mi postali skoro neizdržljivi jer ne mogu dovoljno da se koncentrišem i, pravo da vam kažem, to me i ne interesuje. Veoma rado bih se posvetio svome poslu. Počeo sam, recimo, da pišem jednu knjigu na koju sam dosta polagao, ali ne mogu da radim. Postao sam neurotičan' ['I have made a very great exception for you today. Music long ago left the orbit of my thinking. Because my thoughts are now directed towards something else and consumed with something which somebody would call politics, and which is most certainly not politics at all. I do not concern myself with that. The difference is that, in normal countries, those which are not in the state of war or revolution, the politics changes, and the people are alive and well. Here the question of politics has become the question of existence. Among my friends there are two distinct kinds of individual reactions to this. Some, who are far happier and whom I envy, have succeeded in isolating themselves completely. They do not read newspapers, or watch TV, or listen to the radio, they read their books and concern themselves with scientific work, and have thus succeeded in holding on to their sanity. The others, like me, can not tear themselves away from all this, so that thinking about music is very far from me. Concerts have become almost unbearable because I can hardly concentrate and, to tell you the truth, I am not interested in them. I would like to devote myself to work. I have, for example, begun to write a book from which I expected a a great deal, but I cannot work. I have become neurotic.'] (21).

46 Jasmina Zec, 'Muzika nije samo muzika. Razgovor sa Enrikom Josifom' ['Music is not Only Music. An Interview with Enriko Josif'], 4/5, 1994, 5-10. 
'Nalazimo se u vremenu kada prvu reč nema više stvaralaštvo, nego izvođaštvo. Izvođačko stvaralaštvo je u ovom veku najveće otkad postoji izvođaštvo, a ono je vezano za veliku duhovnu krizu vremena - stvaralačku duhovnu krizu.

Analitički nož je razorio stvaralaštvo. Pustošno sečivo se nasladno, samrtnički ustremilo na samu srž tajne duhovnosti, u samu srž pesmenog i njene pesmenosti, u samu srž tajne duše i njene duševnosti, razdirući plodove života i mrtvorođene otpatke ogromnih razmera apokaliptičke sablazni.'

['We live in times when the priority is no longer creation, but performance. Performing creativity in this century is the greatest since performing has existed, and it is related to the great spiritual crisis of the time - the creative spiritual crisis.

The analytical knife has annihilated creativity. The destructive blade has wantonly, murderously lashed into the very core of the secret of spirituality, into the very core of poetics and its poetry, into the very core of the secret of the soul and its soulfulness, tearing apart the fruits of life and the stillborn debris of enormous proportions of the apocalyptical scandal.' $]^{47}$

It is very interesting that these words were published in the same issue with the interview with Vlastimir Peričić by Dejan Despić, who presented the esteemed composer, scientist and pedagogue, authentically revealing the important aspects of his personality: modesty, forebearance, symbolizing the very opposite idea - the possibility of joining and reconciling what others considered irreconcilable.

The texts of the interviews can be read today not only as a testimony of the past, but equally as a testimony of the time when the interviews were conducted, thus presenting a certain chronicle of a musical moment.

5. This retrospection of the contributions in the Composer Speaks section will be concluded by a statistical review: a table survey of the subjects interviewed for New Sound, among domestic authors (composers and musicologists), according to the generation of composers (the authors were listed according to the year of their birth).

\begin{tabular}{|l|l|l|}
\hline $\begin{array}{l}\text { The decade } \\
\text { of birth }\end{array}$ & Authors & Issue number \\
\hline $1900-1910$ & $\begin{array}{l}\text { Mihovil Logar, Ljubica Marić, Stanojlo Rajičić } \\
\text { Ljubica Marić }\end{array}$ & \begin{tabular}{l}
23 \\
\hline
\end{tabular} \\
\hline
\end{tabular}

Ibid., 8. 


\begin{tabular}{|c|c|c|}
\hline $1911-1920$ & $\begin{array}{l}\text { Nikola Hercigonja } \\
\text { Vitomir Trifunović } \\
\text { Dragoslav Dević, Erne Kiralji }\end{array}$ & $\begin{array}{c}3 \\
22 \\
17\end{array}$ \\
\hline $1921-1930$ & $\begin{array}{l}\text { Miloš Velimirović } \\
\text { Dragutin Gostuški, Vlastimir Peričić } \\
\text { Zlatan Vauda } \\
\text { Enriko Josif } \\
\text { Aleksandar Obradović } \\
\text { Dušan Radić } \\
\text { Nadežda Mosusov } \\
\text { Dejan Despić }\end{array}$ & $\begin{array}{l}26 \\
2 \\
23 \\
4 / 5 \\
10 \\
11 \\
21 \\
15\end{array}$ \\
\hline $1931-1940$ & $\begin{array}{l}\text { Vladan Radovanović } \\
\text { Rajko Maksimović } \\
\text { Marija Bergamo } \\
\text { Mirjana Živković } \\
\text { Rastislav Kambasković }\end{array}$ & $\begin{array}{c}9 \\
6 \\
35 \\
25 \\
27\end{array}$ \\
\hline $1941-1950$ & $\begin{array}{l}\text { Srđan Hofman } \\
\text { Milan Mihajlović } \\
\text { Ivan Jevtić } \\
\text { Ivana Stefanović } \\
\text { Zoran Erić }\end{array}$ & $\begin{array}{c}3 \\
24 \\
8 \\
14 \\
13\end{array}$ \\
\hline $1951-1960$ & $\begin{array}{l}\text { Miloš Petrović } \\
\text { Žarko Mirković } \\
\text { Dimitrije Golemović } \\
\text { Miloš Raičković }\end{array}$ & $\begin{array}{l}13 \\
20 \\
28 \\
38\end{array}$ \\
\hline 1961-1970 & $\begin{array}{l}\text { Katarina Miljković } \\
\text { Isidora Žebeljan } \\
\text { Anja Đorđević }\end{array}$ & $\begin{array}{l}31 \\
29 \\
36\end{array}$ \\
\hline
\end{tabular}

The retrospective of the content of the Composer Speaks section on the occasion of the twentieth anniversary of New Sound magazine was written principally with the purpose of summing up and classifying the results, but, at the same time, it presented an opportunity to reconsider the methodological issues regarding the role of the interview in musicology. Therefore, modern theoretical conceptions about the interview as a method and technique of research provided the basis for critical consideration of the contributions published so far. Although the interview necessarily implies the interaction of the interviewer and 
the subject of the interview, this analysis of the contributions published in the Composer Speaks section confirms that the soundly established methodological basis of the interview is a prerequisite for the realization of its purpose.

Translated by Goran Kapetanović

\section{BIBLIOGRAPHY}

Adamović, Dragoslav, Razgovori sa savremenicima, Beograd, Privredna štampa, 1982.

Bryman, Alan, Interviewing in qualitative research, In Social Reaserch Methods, New York, Oxford University Press, 2001, from http://peoplelearn.homestead.com/MEdHOME/ QUALITATIVE/Chap15.Interview.pdf, acc. 9.3.12.

Craft, Robert and Igor Stravinsky, Dialogues and a Diary, London, Faber and Faber, 1968. Jevtić, Miloš, Muzika između nas: Odgovori 2, Knjaževac, Nota, 1979.

Johnson, Sarah Anne, The Art of the Author Interview and Interviewing Creative People, Lebanon, University Press of New England, 2005.

Kvale, Steinar, Interviews: An introduction to qualitative research interviewing, Newbury Park, CA: Sage, 1996, from http://www.insideinstallations.org/OCMT/mydocs/Microsoft\%20Word\%20-\%20Booksummary_Interviews_SMAK_2.pdf, acc. 9.3.12.

Milić, Vojin, Sociološki metod (treće izdanje), Beograd, Zavod za udžbenike, 1996.

Richardson, S. A. et al., Interviewing - Its forms and Functions, New York, Basic Books, 1965.

Roulstone, Kathryn, Reflective Interviewing: A guide to Theory and Practice, London, SAGE Publication, 2010.

Wrench, Jasopn S. et. al., Quantitative Research Methods for Communication, New York, Oxford University Press, 2008.

Novi Zvuk / New Sound:

Blažeković, Zdravko, Vizantista srpskog porekla. Razgovor sa muzikologom Milošem Velimirovićem, 26, 2005, 40-52.

Veselinović Hofman, Mirjana, Odgovornost nalaženja prave ravnoteže. Razgovor sa Eduardom P. Mirandom, 20, 15-26.

Veselinović Hofman, Mirjana, REČ MUZIKOLOGA: Prima la musica kao muzikološki kredo. Razgovor sa Dejvidom Felouzom, 29, 2007, 5-11.

Vuksanović, Ivana, Komunikacija kao imperativ stvaranja. Razgovor sa Rajkom Maksimovićem, 6, 1995, 5-15.

Despić, Dejan, Razgovor sa Vlastimirom Peričićem, 2, 1993, 5-10.

Dokmanović, Jasminka, REČ ETNOMUZIKOLOGA: Bard etnomuzikologije. Razgovor sa Dragoslavom Devićem, 17, 2000, 5-12.

Erić, Zoran, Onome ko leti ne trebaju krila. Intervju sa Milošem Petrovićem, 13, 1999, 15-21.

Žižić, Bojana, Razgovor sa dr. Dragutinom Gostuškim, 2, 1993, 11-21. 
Zec, Jasmina, Muzika nije samo muzika. Razgovor sa Enrikom Josifom, 4/5, 1994, 5-10.

Kaufman, Diter, Koga ljubi deseta muza ili rođenje akuzmatične umetnosti iz duha muzike, 26, 2005, 33-39.

Kara Pešić, Ana, Jedino je tišina bogata. Razgovor sa Ivanom Stefanović, 14, 5-14.

Kotevska, Ana, Miris moderne slobode. Imaginarni razgovor sa Milojem Milojevićem, 7 , 1996, 5-14.

Kotevska, Ana, Komunikacija otvorenim putevima. Razgovor s Dejanom Despićem, 15, 2000, 17-27.

Kotevska, Ana, Isidora Žebeljan: transcendentalna putovanja do i od beogradske fantastike, 29, 2007, 13-21.

Kulezić, Danijela, Razgovor sa Mihovilom Logarom, 1, 1993, 13-16.

Kulezić Vilson, Danijela, REČ MUZIKOLOGA Lična poruka u boci. Razgovor sa Anom Kotevskom, 33, 2009, 1-10.

Makević, Zorica, Vreme koje nas nosi dalje. Razgovor sa Ljubicom Marić, 1, 1993, 9-12.

Makević, Zorica, ...Pojanje, pojanje..., 23, 2004, 7-9.

Marinković, Sonja, Razumeti početak i kraj. Intervju sa kompozitorom Aleksandrom Obradovićem, 10, 1997, 5-16.

Marinković, Sonja, Eho slika samoće. Razgovor sa Žarkom Mirkovićem, 20, 5-14.

Marinković, Sonja, Ukloniti šablone i klišea. Razgovor sa Nadeždom Mosusovom, 21, 2003, 9-14.

Marinković, Sonja, Invencija je važnija. Razgovor sa Milanom Mihajlovićem, 24, 2004, $7-21$.

Marić, Ljubica, Monotematičnost i monolitnost oblika fuge, 23, 2004, 10-15.

Marić, Ljubica, Razgovor sa Azrom, 23, 2004, 16

Marić, Ljubica, Tablice, 23, 2004, 17-27.

Miljković, Katarina i Nada Kolundžija, Kompozitor i njegov izvođač:12 dana, 31, 2008, $5-17$.

Novak, Jelena, Sve je dosegnuto. Razgovor sa Filipom Glasom, 14, 15-21.

Novak, Jelena, Muzika o muzici. Razgovor a Lujem Andrisenom, 18, 5-19.

Novak, Jelena, Trenirane razlike. Razgovor sa Stivom Rejšom, 22, 2003, 12-20.

Novak, Jelena, Muzika o nestajanju vremena. Razgovor sa danskim kompozitorom Ivarom Frunbergom, 26, 2005, 53-60.

Novak, Jelena, Plima zvuka. Razgovor sa Migelom Azgimom, 30, 2007, 5-12.

Pantić, Vojislav, Ples zvučnih skulptura. Razgovor sa Marijom Šnajder, 19, 16-31.

Pantić, Vojislav, Žudnja u srcu stvaranja. Razgovor sa Bredom Meldouom, džez pijanistom, 21, 2003, 15-28.

Perković Radak, Ivana, Stvaranje je jedno i uvek isto... Razgovor sa Dimitrijem Golemovićem, 28, 2006, 7-15.

Petrović, Miloš, Ovo nije igra u kojoj se može dobiti ili izgubiti. Intervju sa Zoranom Erićem, 13, 1999, 9-13.

Petrović, Tatjana, Traganja za melodijom. Razgovor sa Ivanom Jevtićem, 8, 1996, 5-10. 
Petrović, Tatjana, Publiku volim da ščepam za grlo. Razgovor s Rodionom Ščedrinom, 15, 2000, 28-31.

Pilipović, Gorica, Poreklo se ne može sakriti. Razgovor sa Dušanom Radićem, 11, 1998, $5-12$.

Poljanski, Branko Ve, REČ O FUTURIZMU: Povodom stote godišnjice Manifesta futurizma, Dijalog Marineti - Poljanski, 34, 2009, 1-6.

Popović, Tijana, Višestrukost i koherentnost. Razgovor sa Srđanom Hofmanom, 3, 1994, $11-18$.

Prodanov, Ira, Mora da je strašno - ne stvarati. Razgovor sa Erneom Kiraljem, 19, 5-15.

Radeta, Igor, Interview with Krzysztof Penderecki, 37, 2011, 5-14.

Radovanović, Vladan, Intervju u ogledalu, 9, 1997, 5-12.

Radović, Branka, Utopija ili zbilja: put od popularne pesme do simfonije i opere. Razgovor sa Nikolom Hercigonjom, 3, 1994, 5-10.

Radović, Branka, Traganje za kompozitorskim i ljudskim identitetom. Razgovor sa Rastislavom Kambaskovićem, 27, 2006, 5-17.

Radoman, Valentina, From Minimalism to Classicism: A Composer's Journey Interview with Miloš Raičković, 38, 2011, 5-15.

Sabo, Anica, Tri akorda Zlatana Vaude. Razgovor sa kompozitorom, 23, 2004, 28-33.

Sabo, Anica, Polifonija pedagoškog, teorijskog i kompozitorskog rada 35. Mirjane Živković. Razgovor sa Mirjanom Živković, 25, 2005, 5-11.

Savić, Svetlana, Novi zvučni recepti Ditera Kaufmana. Razgovor sa kompozitorom, 26, 2005, 27-32.

Stevanović, Ksenija, Vocalise and the Experience of the prosopopoeia of Anja Đorđević, 36, 2010, 5-12.

Stefanija, Leon, REČ MUZIKOLOGA: A Conversation with Marija Bergamo, 35, 2010, $5-16$.

Stojanović Novičić, Dragana, Moja dela žive. Razgovor sa Vitomirom Trifunovićem, 22, 2003, 5-11.

Tomašević, Katarina, Razgovor sa Stanojlom Rajičićem, 1, 1993, 17-28. 